\title{
PERBANDINGAN DENYUT NADI ANTARA PENDUDUK YANG TINGGAL DI DATARAN TINGGI DAN DATARAN RENDAH
}

\author{
${ }^{1}$ Ivanny Kasenda \\ ${ }^{2}$ Sylviah Marunduh \\ ${ }^{2}$ Herlina Wungouw
}

\author{
${ }^{1}$ Kandidat Skripsi Fakultas Kedokteran Universitas Sam ratulangi Manado \\ ${ }^{2}$ Bagian Fisiologi Fakultas Kedokteran Universitas Sam Ratulangi Manado \\ Email: Ivannythya@gmail.com
}

\begin{abstract}
The pulse is a pressure that is delivered in the form of a wave when the heart pumped up blood around the body. Pulse is determined by the elasticity of blood vessels. There are research showing the difference in pulse rate in the highlands and lowlands. This research aimed to determine the ratio between the pulse of the people that live in the highlands (mountain area) and lowlands (coastal area). This research is an analytic method using cross sectional study. The subjects of this research is 80 people living in the highlands and 80 people living in the lowlands. The subjects are 18-65 years, physically and mentally healthy and they have been living at the area for 5 years. The data were analyzed using non-parametric test Mann Whitney test. Based on the results of the Mann Whitney statistical test, it shows that there is a difference between the result of pulse measurement of the people living in the highlands and lowlands with asymp value. Sig. (2-tailed) $\alpha=0: 03(\alpha<0.05)$, which means that there are significant difference between highlands and lowlands. The result of this research can be concluded that there is a significant difference in the measurement of the pulse between people living in the highlands and lowlands.
\end{abstract}

Keywords: Pulse, highlands, lowlands.

\begin{abstract}
Abstrak: Denyut nadi adalah suatu tekanan yang dihantarkan dalam bentuk gelombang saat darah dipompa jantung ke seluruh tubuh. Denyut nadi ditentukan oleh elastisitas pembuluh darah. Terdapat penelitian yang menunjukkan adanya perbedaan denyut nadi di dataran tinggi dan dataran rendah. Penelitian ini bertujuan untuk mengetahui perbandingan denyut nadi antara penduduk yang tinggal di dataran tinggi (daerah pegunungan) dan dataran rendah (daerah pesisir pantai). Jenis penelitian ini adalah bersifat metode analitik dengan pendekatan rancangan cross sectional study. Subjek dari penelitian ini adalah 80 orang yang tinggal di dataran tinggi dan 80 orang yang tinggal di dataran rendah. Subjek berumur 18- 65 tahun, sehat jasmani dan rohani serta tinggal menetap 5 tahun. Data di analisis menggunakan uji non parametrik yaitu uji Mann Whitney. Berdasarkan hasil uji statistik Mann Whitney menunjukkan bahwa ada perbedaan hasil pengukuran denyut nadi antara penduduk yang tinggal di dataran tinggi dan dataran rendah dengan nilai asymp. Sig. (2-tailed) $\alpha=0.03(\alpha<0.05)$ yang berarti terdapat perbedaan yang bermakna antara dataran tinggi dan dataran rendah. Hasil penelitian ini dapat disimpulkan bahwa terdapat perbedaan yang bermakna pada pengukuran denyut nadi antara penduduk yang tinggal di dataran tinggi dan dataran rendah.
\end{abstract}

Kata kunci denyut nadi, dataran tinggi, dataran rendah.

Denyut nadi adalah suatu gelombang yang teraba pada arteri bila darah di pompa keluar jantung. Denyut ini mudah diraba di suatu tempat dimana ada arteri melintas. Darah yang didorong ke arah aorta sistol tidak hanya bergerak maju dalam pembuluh darah, tapi juga menimbulkan gelombang bertekanan yang berjalan sepanjang arteri. 
Gelombang yang bertekanan meregang di dinding arteri sepanjang perjalanannya dan regangan itu dapat diraba sebagai denyut nadi. Denyut yang teraba bukan darah yang dipompa oleh jantung masuk ke aorta melainkan gelombang tekanan yang dialihkan dari aorta yang merambat lebih cepat daripada darah itu sendiri. ${ }^{1}$

Pada jantung manusia normal, tiap-tiap denyut berasal dari nodus SA (irama sinus normal). Semakin besar metabolisme dalam suatu organ, maka makin besar aliran darahnya. $^{2}$ Hal ini menyebabkan kompensasi jantung dengan mempercepat denyutnya dan memperbesar banyaknya aliran darah yang dipompakan dari jantung ke seluruh tubuh. ${ }^{3}$

Denyut nadi normal dapat dikategorikan sesuai umur yaitu: dewasa 60-80, anak 80-100 dan bayi 100-140. Salah satu faktor yang dapat mempengaruhi denyut nadi adalah tempat tinggal. Letak tempat tinggal dapat dibedakan menjadi dua, yaitu dataran tinggi dan dataran rendah. ${ }^{4}$

Dataran tinggi adalah suatu wilayah daerah yang mempunyai ketinggian lebih tinggi dari daerah sekitarnya yaitu pada ketinggian lebih dari $200 \mathrm{~m}$. Di Indonesia terdapat banyak wilayah dataran tinggi. Dataran rendah merupakan suatu wilayah daerah yang lebih rendah dari daerah sekitarnya. Daerah ini mempunyai ketinggian mencapai $200 \mathrm{~m}$ di atas permukaan laut. ${ }^{5,6}$

Pada suatu penelitian yang dibuat oleh mahasisiwa Fakultas Kedokteran Universitas Udayana dengan sampel dataran rendah daerah Manado dan dataran tinggi daerah Rurukan mendapatkan hasil lebih tinggi denyut nadi dari sampel dataran rendah daripada dataran tinggi. ${ }^{7}$

Dari penelitian itu maka penulis tertarik untuk membuat penelitian tentang perbandingan denyut nadi antara dataran tinggi dan dataran rendah.

\section{METODE PENELITIAN}

Jenis penelitian ini adalah desain analitik dengan rancangan potong lintang (cross sectional study). Penelitian ini dimaksud untuk mengetahui perbandingan denyut nadi antara penduduk di dataran tinggi dan dataran rendah. Pada penelitian ini yang menjadi subjek penelitian adalah penduduk di daerah Rurukan dan Malalayang. Pengambilan sampel diambil dari sebagian populasi penduduk dataran tinggi daerah Rurukan dan dataran rendah Malalayang dengan memenuhi kriteria inklusi yaitu berumur 18-65 tahun, tinggal menetap minimal 5 tahun, sehat jasmani dan rohani saat diperiksa dan bersedia menjadi responden. Definisi operasional yang digunakan yaitu Denyut nadi adalah denyut yang dapat dirasakan saat meraba bagian tubuh yang terdapat pembuluh darah arteri. Denyut nadi normal 60-100 kali per menit. Dataran tinggi adalah bagian permukaan bumi yang letaknya lebih tinggi dari daerah disekitarnya. Letak ketinggian diatas $200 \mathrm{~m}$ di atas permukaan laut. Dataran rendah adalah bagian permukaan bumi yang letaknya lebih rendah dari daerah disekitarnya. Letak ketinggian dibawah 200 m di atas permukaan laut.

\section{HASIL PENELITIAN DAN BAHASAN}

Penelitian ini dilakukan di dua tempat yaitu di dataran tinggi dan dataran rendah. Daerah dataran tinggi yang dipilih adalah Desa Rurukan dan dataran rendah adalah pesisir pantai Malalayang. Desa Rurukan memiliki jumlah penduduk 1763 orang dan 446 KK. Malalayang memiliki jumlah penduduk 704 orang dan 230 KK. Responden pada penelitian ini adalah penduduk dataran tinggi dan dataran rendah yang berumur 1865 tahun yang telah tinggal menetap diatas 5 tahun. Dataran tinggi di Desa Rurukan sebanyak 80 orang. Dataran rendah di Pesisir Pantai Malalayang sebanyak 80 orang. Responden diukur denyut nadinya dan dilihat perbandingannya antara dataran tinggi dan dataran rendah.

\section{Distribusi berdasarkan jenis kelamin dataran tinggi dan dataran rendah}

Pada Tabel 1 dapat dilihat jumlah responden perempuan (51 orang; 63,75\%) lebih banyak daripada responden laki-laki (29 orang; 36,25\%) di dataran tinggi. 
Kasenda, Marunduh, Wungouw; Perbandingan Denyut Nadi...

Sedangkan jumlah responden laki-laki (42 orang; 52,5\%) lebih banyak daripada responden perempuan (38 orang; 47,5\%) di dataran rendah.

Tabel 1. Distribusi berdasarkan jenis kelamin dataran tinggi dan dataran rendah

\begin{tabular}{lllll}
\hline \multicolumn{1}{c}{ Jenis Kelamin } & \multicolumn{2}{c}{ D. Tinggi } & \multicolumn{2}{c}{ D. Rendah } \\
& $\mathrm{n}$ & \multicolumn{1}{c}{ \% } & $\mathrm{n}$ & \multicolumn{1}{c}{ \% } \\
\hline Laki-laki & 29 & 36,25 & 42 & 52,5 \\
Perempuan & 51 & 63,75 & 38 & 47,5 \\
\hline Total & 80 & $100 \%$ & 80 & $100 \%$ \\
\hline
\end{tabular}

\section{Distribusi berdasarkan umur responden dataran tinggi dan dataran rendah}

Pada Tabel 2 dapat dilihat umur responden di dataran tinggi yang paling mendominasi adalah umur 41-50 tahun yaitu 30 orang atau sekitar $37,5 \%$ dan paling sedikit adalah umur 18-30 yaitu 9 orang atau sekitar 11,25\%. Sedangkan umur responden di dataran rendah yang paling mendominasi adalah umur 41-50 tahun yaitu 23 orang atau sekitar 28,75\% dan paling sedikit adalah umur 31-40 yaitu 17 orang atau sekitar $21,25 \%$.

Tabel 2. Distribusi berdasarkan umur responden dataran tinggi dan dataran rendah

\begin{tabular}{lcccc}
\hline Umur & \multicolumn{2}{c}{ D. Tinggi } & \multicolumn{2}{c}{ D. Rendah } \\
& $\mathrm{n}$ & $\%$ & $\mathrm{n}$ & $\%$ \\
\hline $18-30$ & 9 & 11,25 & 20 & 25 \\
$31-40$ & 20 & 25 & 17 & 21,25 \\
$41-50$ & 30 & 37,5 & 23 & 28,75 \\
$51-65$ & 21 & 26,25 & 20 & 25 \\
& & & & \\
\hline Total & 80 & $100 \%$ & 80 & $100 \%$ \\
\hline
\end{tabular}

Distribusi berdasarkan pekerjaan pada responden dataran tinggi dan dataran rendah

Pada Tabel 3 dapat dilihat responden Dataran Tinggi paling banyak adalah petani yaitu 30 orang $(37,5 \%)$, diikuti oleh IRT 23 orang $(28,75)$ sedangkan paling sedikit yaitu pensiunan yaitu 1 orang (1,25\%). Responden dataran rendah paling banyak adalah IRT yaitu 29 orang $(36,25 \%)$ dikuti oleh swasta 22 orang $(27,5)$ dan nelayan 17 orang (21,25\%) sedangkan paling sedikit yaitu pensiunan dan mahasiswa yaitu masingmasing 1 orang $(1,25 \%)$.

Tabel 3. Distribusi berdasarkan pekerjaan pada responden dataran tinggi dan dataran rendah

\begin{tabular}{lcccc}
\hline Pekerjaan & \multicolumn{2}{c}{ D. Tinggi } & \multicolumn{2}{c}{ D. Rendah } \\
& $\mathrm{n}$ & $\%$ & $\mathrm{n}$ & $\%$ \\
\hline Petani & 30 & 37,5 & 2 & 2,5 \\
IRT & 23 & 28,75 & 29 & 36,25 \\
Nelayan & \multicolumn{2}{c}{-} & 17 & 21,25 \\
PNS & 8 & 10 & 3 & 3,75 \\
Wiraswasta & 7 & 8,75 & 2 & 2,5 \\
Swasta & 4 & 6,25 & 22 & 27,5 \\
Mahasiswa & 3 & 3,75 & 1 & 1,25 \\
Pensiunan & 1 & 1,25 & 1 & 1,25 \\
Tidak ada & 3 & 3,75 & 4 & 5 \\
& & & & \\
\hline Total & 80 & 100 & 80 & 100 \\
\hline
\end{tabular}

\section{Distribusi denyut nadi responden dataran tinggi dan dataran rendah berdasarkan umur}

Pada Tabel 4 dapat dilihat denyut nadi responden dataran tinggi dan dataran rendah berdasarkan umur.

Tabel 4. Distribusi denyut nadi responden dataran tinggi dan dataran rendah berdasarkan umur

\begin{tabular}{lcccc}
\hline Umur & \multicolumn{2}{c}{ D. Tinggi } & \multicolumn{2}{c}{ D. Rendah } \\
& \multicolumn{2}{c}{ rata-rata } & \multicolumn{2}{c}{ rata-rata n } \\
& DN(x/mnt) & \multicolumn{2}{c}{ DN(x/mnt) } & \\
\hline $18-30$ & 76,4 & 19 & 72,4 & 20 \\
$31-40$ & 75,2 & 20 & 79,05 & 17 \\
$41-50$ & 70,8 & 30 & 79,13 & 23 \\
$51-65$ & 72 & 21 & 77,6 & 20 \\
& & & & \\
\hline Total & & 80 & & 80 \\
\hline
\end{tabular}

Di dataran tinggi rata- rata denyut nadi yang paling tinggi adalah responden 
berumur 18-30 tahun yaitu 76,4x/menit dan paling rendah adalah responden berumur 4150 yaitu 70,8x/menit. Sedangkan di dataran tinggi rata-rata denyut nadi yang paling tinggi adalah responden berumur 41-50 tahun yaitu $79,13 \mathrm{x} /$ menit dan paling rendah adalah responden berumur 18-30 yaitu $72,4 x /$ menit.

\section{Distribusi responden berdasarkan pola hidup di dataran tinggi dan dataran rendah}

Pada Tabel 5 dapat dilihat pola hidup responden di dataran tinggi dan dataran rendah. Di dataran tinggi responden yang merokok yaitu 13 orang atau sekitar 15\% sedangkan di dataran rendah yaitu 34 orang atau sekitar 42,5\%. Di dataran tinggi responden yang mengkonsumsi alkohol yaitu 18 orang atau sekitar 22,5\% sedangkan di dataran rendah yang mengkonsumsi alkohol yaitu 25 orang atau sekitar 31,25\%.

Tabel 5. Distribusi responden berdasarkan pola hidup di dataran tinggi dan dataran rendah

\begin{tabular}{|c|c|c|}
\hline \multirow[t]{2}{*}{ Pola Hidup } & D. Tinggi & D. Rendah \\
\hline & n $\%$ & $\mathrm{n} \quad \%$ \\
\hline Merokok & 1315 & $34 \quad 42,5$ \\
\hline Alkohol & 1822,5 & 2531,2527 \\
\hline Stress & 33,75 & $20 \quad 25$ \\
\hline Olahraga & 3037,5 & 4353,75 \\
\hline R. Hipertensi & 4353,75 & 5973,75 \\
\hline
\end{tabular}

Di dataran tinggi responden yang sedang stress yaitu 27 orang atau sekitar $33,75 \%$ sedangkan di dataran rendah yaitu 20 orang atau sekitar $25 \%$. Di dataran tinggi responden yang rutin olahraga yaitu 30 orang atau sekitar 37,5 \% sedangkan di dataran rendah yaitu 43 orang atau sekitar $53,75 \%$. Di dataran tinggi responden yang mempunyai riwayat hipertensi yaitu 43 orang atau sekitar 53,75 \% sedangkan di dataran rendah yaitu 59 orang atau sekitar $73,75 \%$.

\section{Perbandingan denyut nadi responden dataran tinggi dan dataran rendah}

Pada Tabel 6 dapat dilihat responden di Dataran Tinggi memiliki rata-rata denyut nadi $69,84 x /$ menit sedangkan responden di Pesisir pantai Malalayang memiliki rata-rata denyut nadi 91,16x/menit.

Tabel 6. Perbandingan denyut nadi responden dataran tinggi dan dataran rendah

\begin{tabular}{llc}
\hline \multicolumn{1}{c}{ Lokasi } & Rata DN & $\begin{array}{c}\text { Total DN } \\
(\mathrm{x} / \text { menit })\end{array}$ \\
\hline D. Tinggi & 69,84 & 5587 \\
D. Rendah & 91.6 & 7293 \\
\hline
\end{tabular}

\section{Uji statistik denyut nadi responden di dataran tinggi dan dataran rendah}

Pada Tabel 7 dapat terlihat dari hasil tes uji statistik bahwa nilai signifikan yaitu 0,03 sehingga nilai signifikannya $<0,05$ berarti H1 (bermakna) atau terdapat perbedaan yang bermakna pada pengukuran denyut nadi antara penduduk yang tinggal di dataran tinggi dan dataran rendah.

Tabel 7. Uji statistik denyut nadi responden di dataran tinggi dan dataran rendah

\begin{tabular}{cc}
\hline Uji Statistik Mann-Whitney U & Hasil Tes \\
\hline Asymp. Sig. (2-tailed) & 003 \\
\hline
\end{tabular}

Berdasarkan hasil penelitian dapat terlihat bahwa terdapat perbedaan antara denyut nadi di dataran tinggi dam dataran rendah. Denyut nadi merupakan tanda langsung tekanan darah dan detak jantung yang dikendalikan oleh sistem saraf otonom, yaitu saraf simpatik dan saraf parasimpatik.

Pada Tabel 4 dapat dilihat denyut nadi responden. Di dataran tinggi rata-rata denyut nadi yang paling tinggi adalah responden berumur 18-30 tahun dan paling rendah adalah responden berumur 41-50 Sedangkan di dataran rendah rata-rata denyut nadi yang paling tinggi adalah responden berumur 4150 tahun yaitu dan paling rendah adalah responden berumur 18-30. 
Pada Tabel 6 dapat dilihat responden di Dataran Tinggi memiliki rata-rata denyut nadi $69,84 x /$ menit sedangkan responden di dataran rendah memiliki rata-rata denyut nadi 91,16x/menit. Dari hasil itu dapat disimpulkan bahwa responden di dataran rendah memiliki denyut nadi yang lebih tinggi daripada responden di dataran tinggi.

Pada sebuah penelitian yang dilaksanakan oleh mahasisiwa Fakultas Kedokteran Universitas Udayana dengan sampel dataran rendah daerah Manado dan dataran tinggi daerah Rurukan mendapatkan hasil lebih tinggi denyut nadi dari sampel dataran rendah daripada dataran tinggi daerah Rurukan. $^{7}$

Pada Tabel 5 dapat dilihat pola hidup responden. Responden yang memiliki riwayat hipertensi lebih banyak responden dataran rendah daripada responden dataran tinggi. Seseorang yang mempunyai riwayat hipertensi maka akan berpengaruh pada denyut nadi. Denyut nadi juga akan meningkat bila tekanan darahnya meningkat. ${ }^{3}$

Pada Tabel 5 dapat dilihat Responden yang merokok lebih banyak responden dataran rendah daripada responden dataran tinggi. Sedangkan responden yang mengkonsumsi alkohol lebih banyak responden dataran rendah daripada responden dataran tinggi. Merokok dan alkohol dapat menyebabkan peningkatan tekanan darah dan juga denyut jantung. $^{8}$

Pada Tabel 5 dapat dilihat responden yang rutin olahraga lebih banyak responden dataran tinggi daripada responden dataran rendah. Olahraga dapat meningkatkan frekuensi denyut nadi, ${ }^{9}$ sedangkan responden yang mengalami stress lebih banyak responden dataran rendah daripada responden dataran tinggi. Stres dapat menyebabkan penurunan frekuensi denyut nadi. ${ }^{3}$

Faktor-faktor yang mempengaruhi sehingga denyut nadi responden dataran rendah yaitu pesisir pantai Malalayang lebih tinggi dari denyut nadi responden di dataran rendah Desa Rurukan karena responden di pesisir pantai malalayang sering mengkonsumsi makanan bergaram tinggi yang mengakibatkan tekanan darah tinggi. Tekanan darah tinggi dapat menyebabkan penigkatan frekuensi denyut nadi. Suhu udara yang panas dan aktifitas fisik yang berat mempengaruhi peningkatan denyut nadi di pesisir pantai Malalayang. ${ }^{3}$

Pada Tabel 7 dapat terlihat dari hasil tes uji statistik bahwa nilai signifikan pada penelitian ini adalah 0,03 sehingga nilai signifikannya $<0,05$ berarti H1 (bermakna) atau terdapat perbedaan yang signifikan antara dataran tinggi dan dataran rendah.

\section{SIMPULAN}

Berdasarkan hasil penelitian yang dilakukan Berdasarkan hasil penelitian yang telah didapat maka diperoleh simpulan: Rata-rata denyut nadi tinggi pada responden beumur 18-30 tahun di dataran tinggi dan kelompok umur 41-50 tahun di dataran rendah. Denyut nadi responden dataran rendah (91,16x/menit) lebih tinggi daripada responden di dataran tinggi (69.84/menit). Dari uji statistik Mann Whitney terdapat perbedaan yang bermakna pada pengukuran denyut nadi antara penduduk yang tinggal di dataran tinggi dan dataran rendah.

\section{DAFTAR PUSTAKA}

1. Mustika G.L. Kajian pengetahuan gizi, pola konsumsi, status gizi,denyut nadi dan tekanan darah siswa SMA Negeri Pandeglang [skripsi]. Bogor: Departemen Gizi Masyarakat Fakultas Ekologi Manusia IPB; 2011.

2. Siswantiningsih K.A. Perbedaan Denyut Nadi Sebelum dan Sesudah Bekerja pada Iklim Kerja Panas di Unit Workshop PT. Indo Acidatama Tbk Kemiri, Kebakkramat, Karanganyar [skripsi]. Surakarta: FK Sebelas Maret; 2010.

3. Elly I. Perubahan denyut nadi pada mahasiswa setelah aktivitas naik turun tangga [skripsi]. Semarang: Fakultas Kedokteran Universitas Dipenogoro; 2006.

4. Yukez. Denyut nadi [homepage on the Internet]. 2012 [Diakses 11 November 2013]. Avaible from: http://yukez. wordpress.com/2012/04/10/denyut-nadi/.

5. Bayu A. Perbedaan genus larva lalat tikus wisata mati pada dataran tinggi dan rendah. Universitas Diponegoro Semarang. 2009. 
6. Sugiaryanto. Kondisi geografis dan penduduk asia tenggara. In: Nugraha $P$ editor. Geografi dan sosiologi. Jakarta: Quadra; 2007.

7. Palilingan R. Model Aktifitas Praktikum Lapangan berbasis ergonomic (APeLErg) memperbaiki respon fisiologis tubuh, menurunkan kelelahan dan meningkatkan kinerja dibandingkan dengan model lama
(APeL), pada mahasiswa FMIPA UNIMA. Fakultas Kedokteran Universitas Udayana. 2009.

8. Kartikawati A. Prevelensi dan determinasi Hipertensi. Jakarta: FKM UI; 2008.

9. Sembulingam K, Sembulingam $P$. Denyut nadi. In: Herman RB editor. Buku Ajar Fisiologi Kedokteran (Edisi Kelima). Jakarta: Binarupa Aksara, 2013; p.123-8. 